\title{
Fruiting of Cranberry Uprights Reduces Fruiting the Following Year
}

T.R. Roper

University of Wisconsin, Madison, WI 53706

K.D. Patten

Washington State University, Long Beach Research and Extension Unit, Long Beach, WA 98531

C.J. DeMoranville

University of Massachusetts, East Wareham, MA 02538

\section{J.R. Davenport}

Ocean Spray Cranberries, 1 Ocean Spray Drive, Lakeville-Middleboro, MA 02349

B.C. Strik

Oregon State University, Cowallis, OR 97331

\section{A.P. Poole}

Coos County Extension, 290 North Central, Coquille, OR 97423

Additional index words. Vaccinium macrocarpon, biennial bearing

Biennial bearing of American cranberry (Vaccinium macrocarpon Ait.) uprights has been documented by Strik et al. (1991). Cultivars differed in percent return bloom and percent return fruit within and among commercial growing regions examined.

Flower initiation for next year's cranberry crop begins in late June to early July (Eaton, 1978). Cranberry uprights flower and set fruit during this period. When flowering, fruit set, and bud initiation occur, nonstructural carbohydrate concentrations in uprights are at their minimum (Hagidimitriou and Roper, 1990). Removing new growth of 'Crowley' cranberry uprights during this critical period reduced fruit set more than removing new growth earlier or later (Roper et al., 1992). The developing fruit may inhibit flower bud induction in cranberry (Eaton, 1978) and other fruit crops (Buban and Faust, 1982).

This research was undertaken to document the effect of the previous year's flowering or fruiting on percent return bloom (PRB) and percent return fruit (PRF) on the cranberry cultivars Stevens and Ben Lear in five growing regions-Massachusetts, New Jersey, Wisconsin, Washington, and Oregon.

In Fall or Winter 1990-91, four 2-m transects were selected randomly within a bed for each cultivar at each of three grower sites, except Washington, where there were only two 'Ben Lear' sites. Along each transect, at least 60 uprights that had fruited in 1990 and at least 60 that had not were tagged separately with vinyl tape. Fruiting in 1990 was based on the presence of persistent pedicels on the up-

Received for publication 9 Mar. 1992. Accepted for publication 23 Oct. 1992. We thank John Klueh for the statistical analysis. The cost of publishing this paper was defrayed in part by the payment of page charges. Under postal regulations, this paper therefore must be hereby marked advertisement solely to indicate this fact. rights. Uprights having only pedicels with the dried flower still attached were not tagged. In 1991, after fruit set, 50 tagged uprights per transect were sampled randomly to determine PRB and PRF of at least one viable fruit per upright (Strik et al., 1991).

The experiment was analyzed as a split plot; growing region (state) was the main plot and previous fruiting was the split plot. Replications were nested within state. Means were separated by LSD following a significant $\mathrm{F}$ test.

Nonfruiting uprights in 1990 were more likely to flower and fruit in 1991 for both cultivars and all states (Table 1). This result and those of Strik et al. (1991) suggest that cranberry uprights are biennial bearing.

By taking the mean of all states for 'Ben Lear' uprights that set fruit in 1990, we found that $54 \%$ less produced flowers and $60 \%$ less produced fruit in 1991 than uprights that did not set fruit in 1990 (Table 1). Similarly, of nonfruiting uprights in 1990, 82\% of sampled flowering uprights also set fruit (Table 1). Of uprights that fruited in 1990, only $71 \%$ of flowering uprights set fruit (Table 1). Thus, fruiting in the previous season had an effect on fruit set beyond a reduced flower count in 'Ben Lear', but not in 'Stevens'. However, performing this analysis state by state was not significant.

'Ben Lear' was less likely to bear biennially in Washington and Oregon than in other states (Table 1). The reason for this difference is unknown but may be related to the milder climate in these two areas.

'Stevens' had the lowest PRB and PRF in Wisconsin and the lowest PRF in Washington (Table 1). Fruiting in 1990 had no greater effect on PRF than on PRB; each was reduced $\approx 49 \%$ by the presence of fruit in 1990 .

In all states but Wisconsin, 'Stevens' had PRBs and PRFs equal to or higher than those of 'Ben Lear' (Table 1). In Wisconsin, the trend was reversed, as in 1990. This result suggests that 'Ben Lear' may be more productive in Wisconsin than 'Stevens', but yield data do not support this conclusion (data not $\mathrm{sh}$ ow n ).

In conclusion, uprights that fruited in 1990 were less likely to flower or set fruit in 1991 . Some differences in PRB and PRF were noted by region. These differences may be a function of climate or regional management practices. It still is not clear whether biennial bearing in cranberry is a result of hormonal interaction and regulation, resource limitation, or both.

\section{Literature Cited}

Buban, T. and M. Faust. 1982, Flower bud induction in apple trees: Internal control and differentiation. Hon. Rev. 4:174-203.

Eaton, G.W. 1978. Floral induction and biennial bearing in the cranberry. Fruit Var. J. 32:58-60.

Hagidimitriou, M. and T.R. Roper. 1990. Seasonal changes in nonstructural carbohydrates in cranberry. HortScience 25: 1066. (Abstr.)

Roper, T.R., E.J. Stang, and G.M. Hawker. 1992. Early season leaf removal reduces fruit set and size in cranberry (Vaccinium macrocarpon Ait.). HortScience 27:75.

Strik, B.C., T.R. Roper, C.J. DeMoranville, J.R. Davenport, and A.P. Poole. 1991. Cultivar and growing region influence return bloom in cranberry uprights. HortScience 26:1366-1367.

Table 1. Percent return bloom and return fruit in 1991 for cranberry uprights that had or had not fruited in 1990 , by individual state.

\begin{tabular}{|c|c|c|c|c|c|c|}
\hline \multirow[b]{3}{*}{ State } & \multicolumn{2}{|c|}{ Flowering } & \multicolumn{2}{|c|}{ Fruiting } & \multicolumn{2}{|c|}{ Fruit set } \\
\hline & \multicolumn{2}{|c|}{ Fruited in 1990} & \multicolumn{2}{|c|}{ Fruited in 1990} & \multicolumn{2}{|c|}{ Fruited in 1990} \\
\hline & No $(\%)$ & Yes (\%) & No $(\%)$ & Yes $(\%)$ & No & Yes \\
\hline \multicolumn{7}{|c|}{ Ben Lear } \\
\hline New Jersey & 76 & $29^{*}$ & 70 & $25^{*}$ & 92 & $77^{\mathrm{Ns}}$ \\
\hline Oregon & 60 & $42^{\mathrm{Ns}}$ & 38 & $24^{\mathrm{NS}}$ & 64 & $56^{\mathrm{NS}}$ \\
\hline Washington & 37 & $26^{\mathrm{Ns}}$ & 28 & $18^{\mathrm{Ns}}$ & 74 & $72^{\mathrm{Ns}}$ \\
\hline Massachusetts & 69 & $13^{* *}$ & 66 & $12^{* *}$ & 95 & $92^{\text {Ns }}$ \\
\hline Wisconsin & 81 & $42^{* *}$ & 60 & $28^{* *}$ & 74 & $67^{\mathrm{Ns}}$ \\
\hline Mean & 67 & $31^{* *}$ & 54 & $22^{* *}$ & 82 & $71^{* *}$ \\
\hline \multicolumn{7}{|c|}{ Stevens } \\
\hline New Jersey & 88 & $48^{* *}$ & 80 & $45^{*}$ & 92 & $90^{\mathrm{Ns}}$ \\
\hline Oregon & 76 & $49^{\text {Ns }}$ & 48 & $32^{\mathrm{Ns}}$ & 63 & $60^{\text {Ns }}$ \\
\hline Washington & 84 & $37^{* *}$ & 36 & $15^{* *}$ & 43 & $42^{\mathrm{Ns}}$ \\
\hline Massachusetts & 75 & $41^{*}$ & 66 & $33^{* *}$ & 88 & $83^{\mathrm{NS}}$ \\
\hline Wisconsin & 64 & $22^{* *}$ & 43 & $15^{* *}$ & 68 & $61^{\mathrm{NS}}$ \\
\hline Mean & 78 & $40^{* * *}$ & 55 & $28^{* *}$ & 70 & $70^{\mathrm{Ns}}$ \\
\hline
\end{tabular}

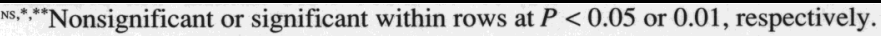

